\title{
Penggunaan Mikroorganisme Lokal dari Berbagai Formula terhadap Kualitas Biourine Kambing Terfortifikasi
}

\author{
The Use of Local Microorganisms from Various Formulas on the Quality of Fortified Goat Biourine
}

\author{
K. Mahmuda ${ }^{1}$, Salundik ${ }^{1}$, \& P. D. M. H. Karti \\ ${ }^{1}$ Departemen Ilmu Produksi dan Teknologi Peternakan, Fakultas Peternakan, Institut Pertanian Bogor \\ ${ }^{2}$ Departemen Ilmu Nutrisi dan Teknologi Pakan, Fakultas Peternakan, Institut Pertanian Bogor \\ Jl. Agatis, Kampus IPB Darmaga Bogor 16680, Indonesia \\ *Corresponding author: khoirulmahmuda@yahoo.co.id \\ (Received 13-12-2019; Revised 28-12-2019; Accepted 02-01-2020)
}

\begin{abstract}
Biourine which is widely known as liquid organic fertilizer is one of the alternative efforts in waste treatment, especially animal urine to become something that is more beneficial for the environment. One of the biourine benefit is to maintain soil fertility which is can increase farmer productivity. The aim of the research was to test the quality of local microorganisms (MOL) and goat biourine which had been made in different formulas, and to determine the best biourine in kale. MOL was made by four main raw materials, they are cow's rumen, golden snail, bamboo shoots, and banana weevil. The making of MOL needed 14 days of processing in aerobic system. Then, 10\% of MOL that had been made was added to goat urine to make biourine in the same aerobic system. The best biourine will be tested by watering kale. From the observations, it was obtained that the composition of raw materials from existing formulas affects the quality of the MOL produced. The quality affects the final result of the biourine. The best selected biourine has $\mathrm{N}$ and $\mathrm{P}$ content of $2.23 \%$ and $0.11 \%$ respectively. The amount of biourine applied to water kale was $0.4 \mathrm{ml}$ / planting hole. The result showed kale which was watered by biourine treatment produced higher production levels than negative control plants but the difference was not significant. But these results was still lower than positive control by the treatment of chemical fertilizers.
\end{abstract}

Keywords: Biourine, Kale Production, Local microorganisms

\section{ABSTRAK}

Biourine yang banyak dikenal dengan nama pupuk organik cair merupakan salah satu alternatif upaya dalam pengolahan limbah terutama urine ternak, untuk menjadi sesuatu yang lebih bermanfaat bagi lingkungan. Adapun salah satu manfaatnya adalah untuk menjaga kesuburan tanah agar produksi yang dihasilkan oleh petani meningkat. Tujuan penelitian ini adalah untuk menguji kualitas mikroorganisme lokal (MOL) dan biourine kambing yang telah dibuat dengan formula berbeda, serta menguji biourine yang terbaik pada tanaman kangkung. MOL dibuat dengan empat bahan baku utama yaitu isi rumen sapi, keong mas, rebung bambu, dan bonggol pisang. Pembuatan MOL dilakukan selama 14 hari dengan sistem aerobik. Adapun 10\% dari MOL yang telah dibuat, ditambahkan kedalam urine kambing untuk pembuatan biourine dengan sistem yang sama yaitu aerobik. Dan biourine terbaik akan diujikan pada tanaman kangkung. Dari pengamatan yang telah dilakukan diperoleh hasil bahwa komposisi bahan baku dari formula yang ada, mempengaruhi kualitas MOL yang dihasilkan. Kualitas tersebut mempengaruhi hasil akhir dari biourine yang dibuat. Adapun biourine terbaik yang dipilih memiliki kandungan $\mathrm{N}$ dan $\mathrm{P}$ sebesar $2.23 \%$ dan $0.11 \%$. Jumlah biourine yang diaplikasikan pada tanaman kangkung sebesar $0.4 \mathrm{ml} /$ lubang tanam. Dengan jumlah tersebut diperoleh hasil bahwa tanaman kangkung dengan perlakuan biourine menghasilkan tingkat produksi yang lebih tinggi dari pada tanaman kontrol negatif akan tetapi perbedaannya tidak signifikan. Namun hasil tersebut masih lebih rendah dari kontrol positif dengan perlakuan pupuk kimia.

Kata kunci: Biourine, Mikroorganisme lokal (MOL), Produksi Kangkung. 


\section{PENDAHULUAN}

Usaha dalam bidang pertanian maupun peternakan di Indonesia semakin berkembang seiring dengan kebutuhan pangan manusia yang meningkat. Untuk memenuhi kebutuhan tersebut, petani meningkatkan produksi melalui intensifikasi pertanian menggunakan pupuk kimia. Penggunaan pupuk kimia secara berlebihan menyebabkan kerusakan fisik pada tanah. Berkembangnya usaha peternakan di sisi lain juga berdampak pada meningkatnya jumlah limbah yang dihasilkan baik padat (feses) maupun cair (urin). Limbah yang tidak diolah dengan baik akan menimbulkan masalah lingkungan seperti menurunnya kualitas udara dan air. Pengolahan limbah perlu dilakukan, salah satunya dengan mengolah menjadi pupuk organik.

Supartha (2012) menyatakan bahwa pupuk organik merupakan hasil dekomposisi bahan-bahan organik baik tumbuhan kering maupun limbah yang dirombak oleh mikroba, pupuk organik sangat penting sebagai penyangga sifat fisik, kimia, dan biologi tanah sehingga dapat meningkatkan efisiensi pupuk dan produktivitas lahan. Salah satu jenis pupuk organik adalah pupuk organik cair yang berasal dari urin hewan ternak. Pupuk cair lebih mudah terserap oleh tanaman karena unsur-unsur di dalamnya sudah terurai dibandingkan pupuk padat. Kelebihan dari pupuk cair adalah mengandung unsur hara makro dan mikro, penyerapan haranya berjalan lebih cepat karena sudah terlarut dibandingkan pupuk padat (Hadisuwito 2007).

Pemanfaatan urin kambing belum seoptimal pemanfaatan feses kambing. Urin kambing berpotensi dijadikan pupuk organik cair atau biourin yang berkualitas karena memiliki kandungan hara yang tinggi. Adapun pengolahannya dapat secara aerobik maupun anaerobik. Pembuatan pupuk organik dapat menambahkan mikroorganisme lokal (MOL). Mikroorganisme lokal adalah larutan hasil fermentasi yang berbahan dasar dari berbagai sumber daya lokal. Larutan MOL mengandung bakteri yang berpotensi sebagai perombak bahan organik, perangsang pertumbuhan, sebagai agen pengendali hama dan penyakit tanaman, serta mengandung unsur hara makro dan mikro (Purwasasmita 2009). Penambahan ini bertujuan untuk mempercepat proses pembuatan pupuk organik cair yang dilakukan secara aerob maupun anaerob. Pembuatan MOL menggunakan bahan baku yang tergolong jenis limbah. Selain dapat mengurangi jumlah limbah, tingginya kandungan hara pada bahan baku juga bermanfaat bagi produktifitas tanaman. Adapun bahan baku yang digunakan berasal dari bahan baku hewani dan nabati.

Beberapa bahan baku dengan jumlah yang melimpah dan kandungan bahan organik yang tinggi adalah Isi rumen sapi, keong mas, bonggol pisang, dan rebung bambu. Isi rumen (ruminal contents) adalah makanan yang belum dicerna secara sempurna oleh lambung pertama ruminansia dan mengandung makro nutrien seperti nitrogen, fosfor, besi, kalium dan kalsium. Rumen ternak ruminansia di dalamnya terdapat berbagai mikroorganisme yang terdiri atas protozoa, bakteri dan fungi ( Novita 2017). Keong mas (Pomacea canaliculata) adalah siput sawah dengan warna cangkang keemasan yang dianggap sebagai salah satu hama dalam produksi padi (Budiono 2006). Rebung bambu menurut Angraeni et al. (2018), mempunyai kandungan $\mathrm{C}$ organik dan giberelin yang tinggi sehingga mampu merangsang pertumbuhan tanaman. Bonggol pisang di dalamnya terdapat jenis mikrobia yang telah teridentifikasi pada MOL bonggol pisang antara lain Bacillus sp., Aeromonas sp., dan Aspergillus nigger (Suhastyo 2011).

Penelitian ini dilakukan untuk mengoptimalisasi urin kambing dan mikroorganisme lokal (MOL) sebagai bahan baku untuk membuat pupuk cair (biourin) yang dapat menjadi salah satu alternatif dalam perbaikan tanah dan meningkatkan produksi tanaman perlu dilakukan.

\section{METODOLOGI PENELITIAN}

\section{Waktu dan Lokasi Penelitian}

Penelitian ini dilaksanakan pada bulan April-Oktober 2019 di Laboratorium Pengolahan Limbah Departemen IPTP Fakultas Peternakan, Laboratorium Kultur Jaringan Departemen INTP Fakultas Peternakan, dan Laboratorium Lingkungan Hidup Departemen BDP Fakultas Perikanan, Institut Pertanian Bogor, Garuda Farm Bogor, serta SMP Cendekia Baznas Bogor. Penelitian ini terdiri atas 3 tahap, yaitu pembuatan mikroorganisme lokal (MOL), pembuatan biourine, dan pengujian biourine pada kangkung.

\section{Tahap 1. Pembuatan Mikroorganisme Lokal (MOL)}

Bahan utama yang digunakan adalah isi rumen sapi, keong mas, bonggol pisang, dan rebung bambu. Komposisi dari masing-masing bahan dapat dilihat pada Tabel 1 . Parameter pada pengujian kualitas MOL adalah sifat kimia, sifat fisik, dan sifat biologi. Adapun alat dan metode yang digunakan pada saat pengujian dapat dilihat pada Tabel 2 dan Tabel 3.

Tabel 1. Formulasi bahan pembuatan mikroorganisme lokal (MOL)

\begin{tabular}{lccccc}
\hline Bahan & \multicolumn{5}{c}{ Formula Bahan } \\
\cline { 2 - 6 } & M1 & M2 & M3 & M4 & M5 \\
\hline Isi Rumen (kg) & 1 & 0.75 & 0.5 & 0.25 & 0 \\
Keong Mas (kg) & 1 & 0.75 & 0.5 & 0.25 & 0 \\
Bonggol Pisang (kg) & 0 & 0.25 & 0.5 & 0.75 & 1 \\
Rebung Bambu (kg) & 0 & 0.25 & 0.5 & 0.75 & 1 \\
Gula Merah (kg) & 1 & 1 & 1 & 1 & 1 \\
Air Kelapa (L) & 1 & 1 & 1 & 1 & 1 \\
Air Cucian Beras (L) & 2 & 2 & 2 & 2 & 2 \\
\hline
\end{tabular}

Tabel 2. Parameter, metode dan alat pada pengujian kualitas MOL berdasarkan sifat kimia dan fisik MOL

\begin{tabular}{cccc}
\hline \multicolumn{2}{c}{ Sifat Kimia } & \multicolumn{2}{c}{ Sifat Fisik } \\
\hline Parameter & Metode/Alat & Parameter & Metode/Alat \\
\hline N Total & Kjeldahl & Suhu & Termometer \\
$\mathrm{P}$ & AAS & TDS & Gravimetri \\
$\mathrm{Fe}, \mathrm{Zn}, \mathrm{Cu}$ & AAS & TSS & Gravimetri \\
\hline \multicolumn{2}{l}{ Keterangan: TDS = total disolved solid, TSS = total suspended } \\
& solid, AAS = atomic absorption spectrophotometer
\end{tabular}


Tabel 3. Parameter dan media pengujian kualitas MOL berdasarkan sifat biologi MOL

\begin{tabular}{ll}
\hline Parameter & \multicolumn{1}{c}{ Media } \\
\hline Mikroorganisme total & $\begin{array}{l}\text { Nutrient Agar (NA) } \\
\text { (Rao 1982) }\end{array}$ \\
Bakteri penambat nitrogen & $\begin{array}{l}\text { Yeast Ekstract Manitol Agar } \\
\text { (YEMA) }\end{array}$ \\
Bakteri pelarut fosfat (BPF) & Pikovskaya (Rao 1982) \\
\hline
\end{tabular}

Tahap 2 Pembuatan Biourine

Tahap kedua adalah pembuatan biourine menggunakan MOL dengan konsentrasi MOL yang ditambahkan sebesar $10 \%$ kedalam urine kambing. Pemberian aerasi dengan aerator dilakukan selama 14 hari. Adapun prosedur pengujiannya sama halnya dengan prosedur pengujian pada MOL.

\section{Tahap 3. Pengujian biourine pada kangkung}

Benih kangkung dibeli di toko pertanian Botani Mart, yang memiliki daya berkecambah (DB) sebesar $80 \%$. Kangkung ditanam pada lahan seluas $1 \times 1 \mathrm{~m}^{2}$. Masingmasing perlakuan terdapat 3 ulangan. Dalam 1 petak terdapat 25 lubang tanam. Masing-masing lubang tanam diisi 5 benih tanaman kangkung. Dengan jarak tanam $20 \mathrm{~cm}$ antar tanaman. Pada penelitian ini terdapat 5 perlakuan, 2 perlakuan sebagai kontrol yaitu kontrol positif dan kontrol negatif, sementara 3 perlakuan lainnya adalah perlakuan biourine, pertama $100 \%$ biourine, kedua biourine yang difortifikasi dengan mikroorganisme potensial tanah, dan yang terakhir adalah biourine yang difortifikasi dengan EM4. Panen dilakukan dengan cara mencabut tanaman kangkung sampai keakarnya. Pengukuran jumlah daun dan tinggi tanaman dilakukan setiap minggu, sementara biomassa segar, berat akar segar, berat batang dan berat daun diukur saat panen.

Data yang terkumpul dianalisis dengan menggunakan analisis sidik ragam untuk mengetahui pengaruh perlakuan dan dilanjutkan dengan uji jarak berganda Duncan. taraf 0.05 untuk mengetahui beda nyata antar perlakuan (Mattjik dan Sumertajaya 2006).

\section{HASIL DAN PEMBAHASAN}

\section{Kualitas MOL dari Berbagai Formula}

Pengujian 5 Mikroorganisme lokal (MOL) yang berbeda menunjukkan hasil yang sangat beragam. Hal tersebut dapat dilihat pada Tabel 4. Semua hasil pengujian pada MOL memiliki kondisi sama yaitu $\mathrm{pH}$ yang asam. Hal ini dapat terjadi karena adanya aktivitas mikroorganisme dalam melepaskan $\mathrm{CO}_{2}$. Terlepasnya $\mathrm{CO}_{2}$ dalam larutan akan membentuk senyawa asam karbonat $\left(\mathrm{H}_{2} \mathrm{CO}_{3}\right)$ yang mudah terurai menjadi ion-ion $\mathrm{H}^{+}$dan $\mathrm{HCO}_{3}^{-}$. Ion-ion $\mathrm{H}^{+}$ini akan menentukan keasaman MOL. Peningkatan konsentrasi ion-ion $\mathrm{H}^{+}$dalam larutan MOL menyebabkan $\mathrm{pH}$ menjadi lebih rendah (Dwijosaputro 2010). Menurut Djuarnani et al. (2005) menyatakan bahwa derajat keasaman pada awal proses pengomposan atau fermentasi akan mengalami
Tabel 4. Nilai pH dan kandungan unsur hara pada MOL dari berbagai formula

\begin{tabular}{|c|c|c|c|c|c|c|c|}
\hline \multirow[t]{2}{*}{ MOL } & \multirow[t]{2}{*}{$\mathrm{pH}$} & \multicolumn{6}{|c|}{ Unsur hara } \\
\hline & & $\mathrm{N}$ & & $\mathrm{P}$ & $\mathrm{Fe}$ & $\mathrm{Zn}$ & $\mathrm{Cu}$ \\
\hline & & \multicolumn{2}{|c|}{-------(\%)----- } & \multicolumn{4}{|c|}{--------------(ppm)-------------- } \\
\hline M1 & 6.12 & 1.15 & 0.100 & 7.41 & & 0.68 & 0.81 \\
\hline M2 & 3.58 & 0.88 & 0.014 & 24.71 & & 1.43 & 0.65 \\
\hline M3 & 3.55 & 0.71 & 0.036 & 22.17 & & 1.27 & 1.03 \\
\hline M4 & 3.41 & 1.30 & 0.008 & 14.98 & & 1.02 & 0.80 \\
\hline M5 & 3.03 & 1.80 & 0.073 & 13.94 & & 0.83 & 0.81 \\
\hline
\end{tabular}

penurunan karena sejumlah mikroorganisme yang terlibat dalam fermentasi mengubah bahan organik menjadi asam organik sehingga terbentuk suasana asam atau terjadi proses pelepasan asam.

Nilai $\mathrm{pH}$ yang rendah pada MOL bonggol pisang dan rebung bambu diduga karena perombakan pada bahan dengan kandungan karbohidrat yang tinggi akan menghasilkan asam asetat. Sementara keong mas mengandung protein yang cukup tinggi selain kandungan bahan yang lain. Menurut Kusarpoko (1994) perombakan protein ini akan menghasilkan nitrogen dan amonia yang bersifat alkalis.

Adapun kandungan unsur hara makro dan mikro juga beragam. Kandungan $\mathrm{N}$ paling tinggi ada pada M5 yaitu $1.18 \%$, hal itu dikarenakan komposisi rebung bambu dan bonggol pisang yang ada pada formula tersebut memiliki jumlah yang paling besar. Sementara untuk kandungan fosfor yang tertinggi adalah M1, hal tersebut dikarenakan pada formula M1, memiliki komposisi isi rumen sapi dan keong mas tertinggi. Sementara sifat fisik MOL dapat dilihat pada Tabel 5 .

Tabel 5. Pengamatan warna dan nilai TDS, TSS pada berbagai jenis formula MOL

\begin{tabular}{lllll}
\hline MOL & \multicolumn{1}{c}{ Warna } & Fase & \multicolumn{1}{c}{ TSS } & TDS \\
\hline & & & $-----\left(\mathrm{mg} \mathrm{L}^{-1}\right)-----$ \\
M1 & Hijau kehitaman & Padat & 9840 & 14060 \\
M2 & Hijau kehitaman & Cair & 1020 & 8780 \\
M3 & Hijau kehitaman & Cair & 995 & 8200 \\
M4 & Hijau kehitaman & Cair & 1180 & 6140 \\
M5 & Orange & Cair & 1950 & 3773 \\
& kekuningan & & & \\
\hline
\end{tabular}

Keterangan : TDS $=$ Total Dissolved Solid, TSS= Total Suspended Solid

Warna MOL merupakan gabungan dari warna bahan baku MOL dalam bentuk koloid. Warna ini tidak akan berubah walaupun mengalami penyaringan dan sentrifugasi (Effendi 2003). Formula M1 memiliki warna hijau kehitaman karena berbahan baku isi rumen dan keong mas. Sementara pada formula M5 berwarna orange kekuningan karena penyusunnya rebung bambu dan bonggol pisang. Semua MOL dengan sumber bahan nabati akan menghasilkan endapan, dan endapan tersebut semakin 
sedikit seiring dengan menurunnya konsentrasi bonggol pisang dan rebung bambu yang diberikan.

Nilai TDS dan TSS pada MOL juga bervariasi. Nilai TDS dan TSS paling tinggi pada formula M1, hal itu karena fase dari MOL 1 mulai dari hari ke-8 sampai hari ke-14 berbentuk padat, sementara untuk MOL yang lain berfase cair. Tingginya TDS dan TSS mengindikasikan bahwa M1 memiliki kandungan bahan organik yang lebih tinggi dari pada formula MOL yang lain. Namun nilai TDS bisa menjadi faktor pembatas bila konsentrasinya terlalu tinggi diberikan pada tanaman. Begitupun dengan nilai TSS, semakin tinggi nilai TSS maka mikroorganisme akan semakin banyak membutuhkan oksigen untuk melakukan dekomposisi pada TSS (Sawardi \& Adrian 2014). Pada M2 sampai M5 memiliki fase cair yang menunjukkan semakin tingginya konsentrasi bahan baku nabati maka TSS pada MOL juga tinggi. Hal itu karena mikroba lebih sulit mendegradasi bahan nabati. sehingga bahan yang mengendapun juga tinggi Adapun keragaman sifat biologi pada MOL dapat dilihat pada Tabel 6.

Tabel 6. Populasi mikroorganisme potensial tanah

\begin{tabular}{|c|c|c|c|c|}
\hline \multirow[t]{3}{*}{ Formula } & \multirow[t]{3}{*}{ BPN } & \multirow[t]{3}{*}{$\mathrm{BPF}$} & \multicolumn{2}{|c|}{ TM } \\
\hline & & & 10-Jun & 10-Jul \\
\hline & & & \multicolumn{2}{|c|}{$\left(\log \mathrm{cfu}^{-1}\right)$} \\
\hline M1 & $1.00 \mathrm{a}$ & $1.00 \mathrm{a}$ & TBUD & 61 \\
\hline M2 & $1.00 \mathrm{a}$ & $1.00 \mathrm{a}$ & TBUD & 36.4 \\
\hline M3 & $1.00 \mathrm{a}$ & $1.00 \mathrm{a}$ & 71.5 & 51 \\
\hline M4 & $1.00 \mathrm{a}$ & $1.00 \mathrm{a}$ & 68.2 & 51.8 \\
\hline M5 & $1.00 \mathrm{a}$ & $1.00 \mathrm{a}$ & TBUD & TBUD \\
\hline
\end{tabular}

Keterangan : BPN= Bakteri Penambat Nitrogen, BPF= Bakteri Pelarut Fosfat, $\mathrm{TM}=$ Total Mikroba

Bakteri Penambat Nitrogen (BPN). Adapun bakteri penambat nitrogen yang diamati adalah Rhizobium sp yang ditumbuhkan pada media spesifik yaitu media YEMA (Yeast Ekstract Manitol Agar). Menurut Khairul (2001) dalam Surtiningsih et al. (2009) menyatakan bahwa salah satu bakteri tanah yang memiliki peranan penting dalam penambatan N2 bebas dari udara sehingga menjadi senyawa nitrogen yang bermanfaat bagi pertumbuhan tanaman adalah Rhizobium. Pengamatan yang dilakukan pada MOL menunjukkan bahwa MOL berbahan baku isi rumen sapi, keong mas, rebung bambu, dan bonggol pisang menunjukkan hasil positif adanya bakteri Rhizobium sp pada semua MOL yang ada. Rhizobium sp ditumbuhkan pada media spesifik dengan pengenceran $10^{-4}$ dan $10^{-5}$ sebanyak 5 kali ulangan.

Bakteri Pelarut Fosfat (BPF). Pengujian MOL menunjukkan hasil yang positif adanya bakteri pelarut fosfat pada semua formulasi yang sudah dibuat. Pada pengenceran tersebut tumbuh bakteri pelarut fosfat yang ditandai dengan terbentuknya zona bening disekitar koloni bakteri. Karena menurut Maryanti (2006) tanda-tanda bahwa suatu bakteri dapat melarutkan fosfat yaitu dengan adanya zona bening pada sekitaran koloni bakteri.

Total Mikrob. Hasil pengamatan menunjukkan bahwa total populasi mikrob terbanyak terdapat pada M5. Hal ini diduga karena tingginya kandungan karbohidrat bonggol pisang dan rebung bambu. Bonggol pisang mengandung karbohidrat sebesar 11.6\% (Rukmana 2005). Tingginya kandungan karbohidrat serta unsur hara makro yang lain dan gula sebagai sumber glukosa, maka sumber makanan pada MOL bonggol pisang dan rebung bambu cukup untuk mendukung pertumbuhan dan perkembangan mikroba.

Karbohidrat adalah substrat utama dalam pertumbuhan mikroba dalam sebuah fermentasi. Sementara menurut Arum (2011) bahwa total mikroba pada MOL yang berbahan dasar keong mas memiliki rata-rata pertumbuhan optimum pada hari ke-7, sedangkan total mikroba pada MOL yang berbahan dasar bonggol pisang memiliki pertumbuhan optimum pada hari ke-14. Hal itu diduga karena pada saat itulah kondisi lingkungan serta sumber bahan makanan untuk mikrob dalam keadaan yang tersedia dan optimum.

\section{Kualitas Biourine dengan Formula MOL yang Berbeda}

Urine merupakan salah satu limbah cair yang dapat ditemukan ketika budidaya ternak. Salah satu yang belum dimanfaatkan secara optimal adalah urine kambing. Seekor kambing dewasa mampu menghasilkan urine sebanyak kurang lebih 0.6-2.5 liter/hari. Adapun kandungan total N dan P yaitu $9181 \mathrm{ppm}$ dan $554.37 \mathrm{ppm}$. Akan tetapi apabila diolah menjadi biourine akan meningkatkan kandungan unsur haranya seperti yang dapat dilihat pada Tabel 7 .

Tabel 7. Nilai pH dan kandungan unsur hara pada biourin dari berbagai jenis formula

\begin{tabular}{lcccccc}
\hline Biourin & $\mathrm{pH}$ & \multicolumn{5}{c}{ Unsur hara } \\
\cline { 3 - 7 } & & $\mathrm{N}$ & $\mathrm{P}$ & $\mathrm{Fe}$ & $\mathrm{Zn}$ & $\mathrm{Cu}$ \\
\hline & & \multicolumn{2}{c}{$------(\%)-----$} \\
B1 & $8.38 \pm 0.06 \mathrm{~b}$ & $1.01 \pm 0.04 \mathrm{~b}$ & $0.08 \pm 0.01 \mathrm{~b}$ & $10.48 \pm 2.54$ & $0.89 \pm 0.10 \mathrm{~b}$ & $0.44 \pm 0.14$ \\
B2 & $8.46 \pm 0.07 \mathrm{~b}$ & $1.37 \pm 0.11 \mathrm{~b}$ & $0.09 \pm 0.00 \mathrm{ab}$ & $11.36 \pm 1.51$ & $1.27 \pm 0.04 \mathrm{a}$ & $0.62 \pm 0.48$ \\
B3 & $8.38 \pm 0.05 \mathrm{~b}$ & $1.20 \pm 0.12 \mathrm{~b}$ & $0.11 \pm 0.01 \mathrm{a}$ & $10.89 \pm 1.49$ & $0.86 \pm 0.07 \mathrm{~b}$ & $0.21 \pm 0.01$ \\
B4 & $8.63 \pm 0.09 \mathrm{a}$ & $2.23 \pm 0.37 \mathrm{a}$ & $0.11 \pm 0.01 \mathrm{a}$ & $9.76 \pm 2.65$ & $0.86 \pm 0.13 \mathrm{~b}$ & $0.48 \pm 0.05$ \\
B5 & $8.46 \pm 0.08 \mathrm{~b}$ & $1.88 \pm 0.42 \mathrm{a}$ & $0.10 \pm 0.03 \mathrm{ab}$ & $9.54 \pm 0.52$ & $0.72 \pm 0.15 \mathrm{~b}$ & $0.28 \pm 0.01$ \\
\hline
\end{tabular}

Keterangan: $\mathrm{B} 1=$ urin $+\mathrm{M} 1, \mathrm{~B} 2=$ urin $+\mathrm{M} 2, \mathrm{~B} 3=$ urin $+\mathrm{M} 3, \mathrm{~B} 4=$ urin $+\mathrm{M} 4, \mathrm{~B} 5=$ urin $+\mathrm{M} 5$, angka-angka pada kolom yang sama diikuti oleh huruf yang sama tidak berbeda nyata pada taraf 0.05 uji Duncan 
Tabel 7 menunjukkan bahwa biourine memiliki nilai $\mathrm{pH}$ yang berbeda, perbedaan tersebut signifikan pada biourine 4 sementara pada biourine lain memiliki perbedaan yang tidak signifikan. Nilai $\mathrm{pH}$ pada biourine $\mathrm{B} 4$, memiliki nilai yang paling tinggi dari pada yang lain yaitu memiliki nilai 8.63. pH pada awal proses fermentasi akan mengalami penurunan karena mikroorganisme yang terlibat dalam pengomposan mengubah bahan organik menjadi asam organik (Djuarni 2008) akan tatapi pada proses selanjutnya akan terjadi peningkatan $\mathrm{pH}$. Fenomena ini sesuai dengan penelitian Sunberg et al. (2004), bahwa nilai pH sering naik antara 8-9. Kandungan unsur hara $\mathrm{N}$ setalah fermentasi sebesar 1-2.2\%. Sementara untuk kandungan $\mathrm{P}$ sebesar $0.08-0.11 \%$. Sehingga proses fermentasi merupakan suatu proses perombakan bahan yang dapat meningkatkan kandungan haranya. Akan tetapi kandungan tersebut masih lebih rendah dari standar. Adapun pada Peraturan Menteri Pertanian Nomor 70/Permentan/SR.140/10/2011 sebesar 3-6\%. Begitu pula pada kandungan unsur yang lain.

Pengujian kualitas biourine tidak hanya dilakukan pada faktor kimia saja, seperti unsur hara makro maupun unsur hara mikro. Namun pengujian kualitas biourine juga dilakukan secara fisika. Adapun parameter yang diuji adalah warna, TSS, dan TDS seperti Tabel 8.

Tabel 8. Pengamatan warna dan nilai TDS, TSS pada berbagai jenis formula biourin

\begin{tabular}{lllc}
\hline Biourin & Warna & TSS & \multicolumn{1}{c}{ TDS } \\
\hline & & $-----------------\left(\mathrm{mg} \mathrm{L}^{-1}\right)$------------------ \\
B1 & Hitam & $756.67 \pm 25.16 \mathrm{a}$ & $8922.33 \pm 3051.91$ \\
B2 & Hitam & $583.33 \pm 40.41 \mathrm{~b}$ & $12337.67 \pm 1086.56$ \\
B3 & Hitam & $600.00 \pm 36.05 \mathrm{~b}$ & $9861.33 \pm 1297.72$ \\
B4 & Hitam & $553.33 \pm 15.27 \mathrm{~b}$ & $11751.67 \pm 1751.62$ \\
B5 & Hitam & $566.67 \pm 20.81 \mathrm{~b}$ & $9850.67 \pm 1833.82$ \\
\hline
\end{tabular}

Keterangan: $\mathrm{B} 1=$ urin $+\mathrm{M} 1, \mathrm{~B} 2=$ urin $+\mathrm{M} 2, \mathrm{~B} 3=$ urin $+\mathrm{M} 3$, $\mathrm{B} 4=$ urin $+\mathrm{M} 4, \mathrm{~B} 5=$ urin $+\mathrm{M} 5, \mathrm{TDS}=$ Total Dissolved Solid, TSS $=$ Total Suspended Solid, angka-angka pada kolom yang sama diikuti oleh huruf yang sama tidak berbeda nyata pada taraf 0.05 uji Duncan.

Proses fermentasi membuat warna urine kambing yang awalnya kuning kemerahan menjadi hitam. Fermentasi bertujuan untuk memecah senyawa komplek menjadi senyawa yang lebih sederhana. Selama proses fermentasi terjadi proses fiksasi $\mathrm{N}$ dari udara oleh mikroorganisme yang ada didalam urine (Indirani 2013). Adapun ciri-ciri pupuk organik cair sudah matang adalah memiliki warna yang lebih gelap, suhu relatif dingin, dan bahan-bahan yang dimasukkan sudah melapuk dan melarut.

Semakin tinggi kandungan TSS maka kecerahan air rendah. Sebaliknya, apabila kandungan TSS rendah, kecerahan air tinggi. Hal ini akan berpengaruh terhadap kualitas kandungan unsur hara (Manurung et al. 2012). Adapun pengaruh MOL terhadap TSS biourine yang dihasilkan berbeda signifikan terhadap perlakuan B1 akan tetapi pada biourine yang lain tidak berbeda secara signifikan. Tingginya TSS pada B1 karena MOL yang ditambahkan pada B1 yaitu M1 juga mengandung TSS yang tinggi, sehingga berkorelasi dengan TSS pada biourine yang dihasilkan.

Konsentrasi benda-benda padat terlarut merupakan jumlah antara kation dan anion di dalam air. TDS terukur dalam satuan parts per million (ppm) atau perbandingan rasio berat ion terhadap air (Agustira et al. 2013). Sementara kandungan TDS pada semua biourine dengan penambahan MOL pada urine dengan formulasi yang berbeda menunjukkan pengaruh yang tidak signifikan. Hal itu karena penambahan MOL sebesar $10 \%$ pada urine kambing merupakan jumlah yang sedikit, sehingga tidak mempengaruhi perbandingan rasio konsentrasi bahan terlarut yang ada di dalam air.

Selain dilakukan pengamatan pada sifat fisik dan kimia, tapi juga dilakukan pengamatan sifat biologi biourine. Kondisi optimum bagi aktivitas mikroba perlu diperhatikan selama proses pengkomposan, misalnya aerasi, media tumbuh dan sumber makanan bagi mikroba (Yuwono 2006). Mikroorganisme akan saling berinteraksi dalam mendegradasi dan memineralisasi senyawa komplek bahan organik menjadi senyawa sederhana dan sejumlah unsur hara esensial seperti N, P dan K. Ketersediaan unsur hara juga merupakan faktor penting dalam pertumbuhan mikroorganisme (Madigan et al 2003; Purwoko 2009; Gunawan et al. 2010).

Pengamatan populasi mikroba pada biourine dilakukan hanya 1 kali yaitu ketika hari ke-14. Pengujian bakteri penambat nitrogen dan bakteri pelarut fosfat diencerkan pada pengenceran 10-1 sampai pengenceran 10-5, sementara untuk total mikroba sampai pengenceran 10-7. Hasil pengujian biourine menunjukkan bahwa mikroorganisme pelarut fosfat dan mikroorganisme penambat nitrogen pada pengenceran 10-4 dan 10-5 bersifat negatif. Hal tersebut diduga dengan penambahan MOL sebanyak $10 \%$ pada urine merupakan konsentrasi yang sedikit, sehingga pada pengenceran 10-4 dan 10-5 keberadaan mikroorganisme pelarut fosfat dan mikroorganisme penambat nitrogen adalah negatif.

Sementara pada pengujian total mikroba dengan pengenceran 10-6 dan 10-7 didapatkan hasil yang tidak bisa untuk dihitung (TBUD), hal tersebut dikarenakan pengumpulan urine kambing yang digunakan sebagai bahan baku dalam pembuatan biourine dilakukan selama 14 hari sehingga dengan pertumbuhan bakteri yang cepat membuat total mikroba yang terdapat di dalam biourine melipah.

\section{Pengujian Biourine pada Kangkung}

\section{Keadaan Umum}

Pengujian biourine pada kangkung dilaksanakan di SMP Cendekia Baznas, Cemplang Kabupaten Bogor. Gardner et al. (1991) menyatakan bahwa pertumbuhan dan hasil suatu tanaman dipengaruhi oleh keadaan lingkungan tumbuhnya. Adapun kandungan unsur hara pada media tanam kangkung yaitu tanah di lingkungan SMP Cendekia Baznas memiliki pH 6.69, total N $0.23 \%$, total P $10.53 \mathrm{mg} /$ $\mathrm{kg}$, Besi $394.51 \mathrm{mg} / \mathrm{kg}$. Pertambahan tinggi kangkung dan jumlah daun dapat dilihat pada Tabel 9. 
Tabel 9. Parameter pertambahan tinggi dan jumlah daun pada kangkung darat per minggu

\begin{tabular}{ccc}
\hline Perlakuan & $\begin{array}{c}\text { Pertambahan tinggi } \\
(\mathrm{cm})\end{array}$ & $\begin{array}{c}\text { Pertambahan jumlah } \\
\text { daun (helai) }\end{array}$ \\
\hline A & $4.17 \pm 0.24$ & $1.78 \pm 0.03 \mathrm{~b}$ \\
B & $4.50 \pm 0.81$ & $2.69 \pm 0.55 \mathrm{a}$ \\
C & $4.01 \pm 0.90$ & $2.01 \pm 0.27 \mathrm{ab}$ \\
D & $3.72 \pm 0.42$ & $2.39 \pm 0.41 \mathrm{ab}$ \\
E & $3.62 \pm 0.87$ & $2.06 \pm 0.43 \mathrm{ab}$ \\
\hline
\end{tabular}

Keterangan: $\mathrm{A}=$ kontrol negatif, $\mathrm{B}=$ pupuk kimia (kontrol positif), $\mathrm{C}=$ biourine terbaik (B4), $\mathrm{D}=$ biourin terbaik (B4) + mikroorganisme potensial tanah, $\mathrm{E}=$ biourin terbaik (B4) + EM4, angka-angka pada kolom yang sama diikuti oleh huruf yang sama tidak berbeda nyata pada taraf 0.05 uji Duncan.

Secara umum pertumbuhan tanaman kangkung dari awal sampai akhir menunjukkan hasil yang baik. Pada parameter pertambahan tinggi perlakuan pupuk tidak menunjukkan respon yang signifikan. Rata-rata pertumbuhan kangkung per minggu sebesar $3.62-4.50 \mathrm{~cm}$ /minggu. Akan tetapi pada parameter pertambahan jumlah daun menunjukkan pengaruh yang. Jika jumlah daun tinggi maka perkiraan produksi juga tinggi. Lingga dan Marsono (2005) menyatakan bahwa dosis pupuk yang tepat merupakan salah satu pertimbangan dalam pertumbuhan tanaman. Ketersediaan unsur hara terutama unsur nitrogen pada tanah dapat memacu pertambahan tinggi tanaman. Adnan et al. (2016), kurang optimalnya pertumbuhan tinggi tanaman yang tidak diberi pupuk adalah karena ketersediaan unsur hara yang rendah sehingga proses pembelahan dan perpanjangan sel pada ujung pucuk tanaman tidak optimal.

Adapun kangkung dipanen saat kangkung saat 44 hst, parameter yang diamati adalah biomassa segar, berat akar, berat batang, dan berat daun, adapun hasilnya dapat dilihat pada Tabel 10.

Pemanenan dilakukan ketika kangkung sudah memiliki ciri-ciri siap panen. Pengaruh pemupukan terhadap pertumbuhan dan produksi tanaman kangkung menunjukkan bahwa pemberian pupuk dapat meningkatkan pertumbuhan dan produksi tanaman. Tania et al. (2012) menyatakan bahwa bila unsur $\mathrm{N}$ cukup tersedia bagi tanaman maka kandungan klorofil pada daun akan meningkat dan proses fotosintesis juga meningkat sehingga asimilat yang dihasilkan lebih banyak. Menurut Edrizal dan Bobiohe (2004), N berperan dalam pertumbuhan vegetatif dan merangsang jumlah anakan.

Parameter biomassa segar, berat batang dan berat daun menunjukkan perbedaan yang signifikan pada kontrol positif. Parameter kontrol positif atau perlakuan dengan pemberian pupuk kimia setiap lubang tanam sebesar $0.8 \mathrm{~g}$ menunjukkan hasil tertinggi. Hal itu karena pada perlakuan $\mathrm{B}$, dosis yang dibutuhkan oleh kangkung untuk tumbuh sudah terpenuhi. Pemberian biourin setiap lubang tanam sebesar $0.4 \mathrm{~mL}$ belum memenuhi kebutuhan. Sehingga perlakuan pupuk kimia dengan dosis 40 kali lebih tinggi dari perlakuan biourin mengakibatkan produksi kangkung yang dihasilkan lebih tinggi.

Parameter berat akar, kangkung yang diberi penambahan pupuk, baik itu pupuk kimia atau pupuk organik, signifikan lebih tinggi daripada kangkung tanpa penambahan pupuk. Hal tersebut karena menurut Lusiana et al. (2013) menyatakan bahwa didalam urin hewan ternak yaitu sapi dan kambing mengandung zat pengatur tumbuh alami golongan auksin, sehingga pemberian biourin yang berasal dari urin kambing membuat berat akar dengan penambahan biourin lebih tinggi dibandingkan tanpa penambahan apapun. Menurut Raihan dan Nurtitayani (2002) peranan bahan organik ada yang bersifat langsung terhadap tanaman, tetapi sebagian besar memengaruhi tanaman melalui perubahan sifat dan ciri tanah.

\section{KESIMPULAN}

Kualitas mikroorganisme lokal (MOL) yang berasal dari isi rumen sapi, keong mas, rebung bambu dan bonggol pisang dengan sistem aerobik memiliki kualitas yang beragam dari sifat kimia, fisik, maupun biologinya. Penambahan MOL sebesar $10 \%$ pada urin kambing, menghasilkan biourin dengan kandungan unsur hara tertinggi pada perlakuan B4 yaitu memiliki kandungan $\mathrm{N}$ dan P sebesar $2.23 \%$ dan $0.11 \%$. Dimana komposisi dari perlakuan B4 adalah 25\% isi rumen sapi keong mas dan $75 \%$ rebung bambu bonggol pisang. Pengaplikasian biourin terhadap tanaman kangkung menunjukkan pengaruh yang signifikan lebih tinggi dari kontrol negatif pada parameter berat akar.

Tabel 10. Biomassa segar, berat akar, berat batang, berat daun tanaman kangkung

\begin{tabular}{|c|c|c|c|c|}
\hline Perlakuan & Biomassa Segar & Berat Akar & Berat Batang & Berat Daun \\
\hline & \multicolumn{4}{|c|}{ 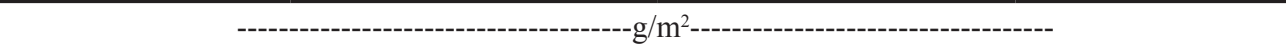 } \\
\hline A & $233.29 \pm 34.85 b$ & $45.69 \pm 6.15 c$ & $100.67 \pm 15.62 b$ & $86.92 \pm 13.13 b$ \\
\hline $\mathrm{B}$ & $560.90 \pm 181.78 \mathrm{a}$ & $115.65 \pm 30.81 \mathrm{a}$ & $240.86 \pm 86.45 \mathrm{a}$ & $204.39 \pm 71.96 \mathrm{a}$ \\
\hline $\mathrm{C}$ & $313.28 \pm 65.76 b$ & $69.64 \pm 12.71 b$ & $135.34 \pm 27.75 b$ & $108.29 \pm 25.60 b$ \\
\hline $\mathrm{D}$ & $305.36 \pm 0.10 b$ & $70.62 \pm 9.17 \mathrm{~b}$ & $125.37 \pm 1.01 \mathrm{~b}$ & $109.37 \pm 8.27 \mathrm{~b}$ \\
\hline $\mathrm{E}$ & $329.40 \pm 144.38 b$ & $64.89 \pm 19.33 b c$ & $143.55 \pm 65.84 b$ & $120.96 \pm 59.29 b$ \\
\hline
\end{tabular}

Keterangan: $\mathrm{A}=$ kontrol negatif, $\mathrm{B}=$ pupuk kimia (kontrol positif), $\mathrm{C}=$ biourin terbaik (B4), $\mathrm{D}=$ biourin terbaik (B4) + mikroorganisme potensial tanah, E= biourin terbaik (B4) + EM4, angka-angka pada kolom yang sama diikuti oleh huruf yang sama tidak berbeda nyata pada taraf 0.05 uji Duncan. 


\section{DAFTAR PUSTAKA}

Agustira R, Lubis KS, Jamilah. 2013. Kajian karakteristik kimia air, fisika air dan debit sungai pada kawasan DAS Padang akibat pembuangan limbah tapioka. Jurnal Agroekologi. 1(3): 615-625.

Arum A. 2011. Studi mikroorganisme dan sifat kimia mikroorganisme lokal (MOL) yang digunakan pada budidaya padi metode SRI (System of Rice Intensification) [tesis]. Bogor (ID): Institut Pertanian Bogor.

Djuarnani, Kristian B, Setiawan. 2008. Cara Cepat membuat Kompos. Jakarta Selatan (ID): PT Agro Media Pustaka

Dwijoseputro D. 2010. Dasar-dasar Mikrobiologi. Jakarta (ID): Djambatan.

Effendi H. 2003. Telaah Kualitas Air Bagi Pengelolaan Sumber Daya dan Lingkungan Perairan. Yogyakarta (ID): Kanisius.

Endrizal, Julistia B. 2004. Efisiensi penggunaan pupuk nitrogen dengan penggunaan pupuk organik pada tanaman padi sawah. Jurnal Pengkajian dan Pengembangan Teknologi Pertanian. 7(2):118-124

Gardner, Pearce, Mitchell. 1991. Fisiologi Tanaman Budidaya. Jakarta (ID): UI Press.

Gunawan R, Anas I, Hazra F. 2010. Produksi masal inokulum Azotobacter, Azospirillum dan bakteri pelarut fosfat dengan menggunakan media alternatif. Jurnal Tanah Lingkungan. 12(1): 25-30.

Hadisuwito S. 2007. Membuat Pupuk Kompos Cair. Jakarta (ID): PT Agromedia Pustaka.

Kusarpoko B. 1994. Isolasi dan karakterisasi bakteri anaerobik perombak limbah cair pabrik kelapa sawit [tesis]. Bogor (ID): Institut Pertanian Bogor.

Lingga P, Marsono. 2000. Petunjuk Penggunaan Pupuk. Jakarta (ID): Penebar Swadaya.

Lingga P, Marsono. 2003. Petunjuk Penggunaan Pupuk. Jakarta: Penebar Swadaya.

Lusiana, Linda R, Mukarlina. 2013. Respon pertumbuhan stek batang sirih merah setelah direndam dalam urin sapi. Jurnal Protobiont. 2(2): 157-160.
Madigan MT, Martinko JM, Parker J. 2003. Brock Biology of Microorganisms. 10th ed. United States of America (US): Pearson Education International.

Manurung T, Dewi YS, Lekatompessy BJ. 2012. Efektifitas biji kelor (Moringa oleifera) pada pengolahan air sumur tercemar limbak domestik. Jurnal Limit. 8 (1): 37-46.

Purwasasmita M. 2009. Mikroorganisme lokal sebagai pemicu siklus kehidupan dalam bioreaktor tanaman. Seminar Nasional Teknik Kimia Indonesia. 19 -20 Oktober 2009. Bandung (ID): SNTKI.

Purwoko T. 2009. Fisiologi Mikroorganisme. Jakarta (ID): Bumi Aksara.

Raihan S, Nurtitayani. 2002. Pengaruh pemberian bahan organik terhadap $\mathrm{N}$ dan $\mathrm{P}$ tersedia tanah serta hasil beberapa varietas jagung di lahan pasang surut Sulfat masam. Agrivita. 23 : 13-19

Rao S. 1982. Biofertilizer in Agriculture. New Delhi (IN): Oxford and IBH Publising Co.

Rukmana R. 2005. Bertanam Sayuran di Pekarangan. Yogyakarta (ID): Kanisius

Sarwadi, Ardian P. 2014. Pengaruh konsentrasi arang ampas tebu terhadap daya serabnya pada limbah cair kelapa sawit. Jurnal Fisika Unand. 3(3): 128-134.

Sundberg, Smars, Jonsson. 2004. Low pH as an inhibiting factor in the transition from mesophilic to thermophilic phase in composting. bioresource technology. 95: 145150 .

Supartha, I Nyoman Y, Gede W, Gede M. 2012. Aplikasi Jenis Pupuk Organik pada Tanaman Padi Sistem Pertanian Organik. Denpasar (ID): Universitas Udayana

Surtiningsih T, Farida, T Nurhariyati. 2009. Biofertilizer bakteri Rhizobium pada tanaman kedelai (Glycine Max(1) Merr.) Berkala Penel Hayati. 15 : 31-35

Tania N, Astina, dan S. Budi. 2012. Pengaruh pemberian pupuk hayati terhadap pertumbuhan dan hasil jagung semi pada tanah podsolik merah kuning. Jurnal Sains Mahasiswa Pertanian. 1 (1): 10-15.

Yuwono. 2006. Kecepatan dekomposisi dan kualitas kompos sampah organik. Jurnal Inovasi Pertanian. 4(2):116-123. 